\title{
Preparation of Soolanirmoolana Rasa - A Herbo-Mineral Formulation
}

\author{
Aparna $\mathbf{M}^{\mathbf{1}}$, R Rajam ${ }^{2}$ \\ ${ }^{1}$ MD Scholar, Department of Rasasastra and Bhaishajyakalpana, Govt. Ayurveda College, Thiruvananthapuram, \\ Kerala, 695001 \\ ${ }^{2}$ Professor and Head of the Department, Department of Rasasastra and Bhaishajyakalpana, Govt. Ayurveda \\ College, Thiruvananthapuram, Kerala, 695001
}

Corresponding Author: Aparna M

\begin{abstract}
Soolanirmoolana Rasa is a herbo mineral formulation explained in Rasatarangini- Vishopavisha vijnaneeya tarangam under the description of kupilu. It contains rasasindoora, gandhaka, sankha bhasma, saindhava, trikatu, jeeraka, amlavetasa and kupilu. It is prescribed in gastrointestinal diseases associated with pain. The work done on the pharmaceutical aspect of Soolanirmoolana rasa is explained in this research paper. For preparing rasasindoora, parada and gandhaka were subjeceted to sodhana separately, then samagunagandhaka kajjali was prepared and bhavana was done in vatankura kashaya. Sankha was subjected to sodhana first followed by three putas to get sankhabhasma. The upavisha kupilu was also purified, powdered and levigated in ardraka swarasa along with powders of other herbal and mineral drugs and finally rolled into pills having gunja pramana i.e. $125 \mathrm{mg}$ size. The shade dried pills were then measured and stored in airtight glass bottles and kept away from sunlight and moisture. The process was done with $10 \mathrm{~g}$ rasasindoora and a final product of 2134 pills having average weight of $124 \mathrm{mg}$ was obtained.
\end{abstract}

Key Words: Soolanirmoolana rasa, Agnivardhaka, Amahara, Sodhana, Bhavana, Upavisha

\section{INTRODUCTION}

Ayurveda, the science of life, is one of India's traditional health-care systems as well as one of the oldest in the world which offers a holistic approach to maintain the health in the healthy people and to cure diseases and restore health in case of diseased. When it comes to Rasasastra, the drugs of which are known for their fast and specific activity in various chronic conditions, remain in the text books unexplored. Rasoushadhis are having fast action, palatability and good results even with small doses of drug. ${ }^{[1]}$ Soolanirmoolana rasa is one among the unexplored yogas described in Rasatarangini which is a combination of herbal and mineral drugs. ${ }^{[2]}$ The drugs in this yoga are having deepana, pachana, amasoshaka and soolahara properties that help in the pacification of disease. The balya, vrishya and rasayana properties of the components will help to improve the general health also. Preparation of Soolanirmoolana includes the preparation of ingredients such as rasasindoora, sankha bhasma and sudha kupilu choorna. This article is aimed at describing the whole pharmaceutical procedures for the preparation of Soolanirmoolana rasa.

\section{MATERIALS AND METHOD}

The steps involved in the preparation of this formulation are as follows:

1. Collection of Raw drugs

2. Preparation of Soolanirmoolana Rasa

a) Rasasindoora nirmana

b) Sankha bhasma nirmana 
c) Kupilu sodhana

d) Powdering of the ingredients

e) Bhavana of all drugs in ardraka swarasa to prepare the formulation

\section{Collection of Raw drugs}

Parada $\quad(99.5 \%$ pure distilled mercury) and gandhaka (Sulphur powder) were purchased from laboratory supply store. Amlavetasa (fruit rind of Garcinia pedunculata) was collected from HM herbals, Ranchi, Jharkhand and identity was verified by consulting Dravyaguna vijnana department. All other drugs saindhava (Rock salt), sunthi (rhizome of Zingiber officinale), maricha (fruit of Piper nigrum), pippali (fruit of Piper longum), jeeraka (fruit of Cuminum cyminum), kupilu (seeds of Strychnos nux-vomica) were purchased from local suppliers at Thiruvananthapuram, Kerala. Vatankura was collected from Poojappura herbal garden, Govt. Ayurveda College, Thiruvananthapuram. All the herbal drugs were authenticated with the help of Dravyaguna Vijnana department.

\section{Preparation of Soolanirmoolana Rasa}

The preparation of soolanirmoolana rasa includes the following steps:

\section{Rasasindoora nirmana}

Rasasindoora is a kupipakwa Rasayana described in Rasasastra. There are several methods for preparation of rasasindoora in different samhitas. Here the preparation was done as per Rasendrasara Sangraha reference. ${ }^{[3]}$ It involves following stages

\section{- Parada sodhana}

It is the purification of parada by triturating it in different herbal media. In different samhitas different bhavana dravas are mentioned for parada sodhana. The reference from Rasendrasarasangraha is adopted here which mentions kumari swarasa, sodhita chitraka kwatha and kakamachi swarasa as bhavana dravas. ${ }^{[4]}$ 200 g parada was subjected to bhavana in each drava dravya for 8 hours and after each bhavana it was washed with hot water and filtered through a bi-layered cloth.

\section{- Gandhaka shodana}

There are different methods of gandhaka sodhana according to different classics like Dalana, patana, etc. Here kurmaputa method mentioned in Ayurveda prakasha was used for sodhana. ${ }^{[5]}$ A fiveliter wide-mouthed earthen pot was smeared with little quantity of ghrita inside and filled with 3 liters of freshly collected cow's milk. A double-layered cotton cloth was inserted within the mouth with a small depression and knotted with a thread at the neck of pot. $500 \mathrm{~g}$ fine powder of gandhaka was uniformly spread over this and covered with an earthen sarava and sandhibandhana was done with 7 layers of mud smeared cloth. On drying, this was carefully placed inside a pit enclosing the pot up to the above neck portion and coconut husks were placed on the uncovered top portion of the sarava. It was then ignited and was permitted to fume without the presence of a visible flame. New pieces of coconut husk were inserted as the method progressed until 48 pieces of coconut husks were consumed. After attaining ambient temperature, it was taken out and opened. The gandhaka globules were removed from the bottom of the pot, rinsed with hot water, dried on tissue cloth, weighed, and powdered after complete drying.

\section{- Preparation of kajjali for Rasasindoora}

120 g each of sudha parada and very fine sudha gandhaka choorna were taken in a mortar and ground well until the kajjali siddha lakshanas such as varitaratwa, unnama, nishchandratwa, rekhapoornatwa and kajjalabha were satisfied.

\section{- Kajjali bhavana in vatankura kashaya}

Vatankura kashaya was selected as bhavana drava as per Rasendrasara sangraha. ${ }^{[3]}$ Vatankura kashaya was prepared in the ratio mentioned for bhavana 
kashaya nirmana i.e. by boiling one part of dravya with 8 times water and reducing to one eighth portion. $60 \mathrm{ml}$ kashaya was added to completely immerse the kajjali and ground until complete dryness. The process was repeated for 3 times.

\section{- Preparation of kupi and pidhana}

A dark amber coloured glass bottle of $650 \mathrm{ml}$ capacity was wrapped with clay smeared cloth and dried completely. This was repeated for 7 times by wrapping one round of two horizontal cross layers which would uniformly cover the bottle from base to mouth. For making pidhana or lid, a chalk piece was wrapped in clay smeared cloth and dried. The process was repeated till the pidhana fit perfectly inside the mouth of glass bottle. $^{[6]}$

\section{- Rasasindoora nirmana}

A conical iron trough was filled with river sand up to 2 inches. Then the corked kupi was placed at the center and valuka was filled with sand until the sand level reached the neck portion of kupi. $240 \mathrm{~g}$ of vatankura bhavita kajjali was filled in the kupi using a funnel. The kupi was corked again and sand was filled around the mouth of kupi in such a way that only the mouth portion was remained outside. The kupi was kept closed during sand filling to avoid any sand particles falling inside. The whole apparatus containing kupi was carefully placed inside a bhatti and the edges were pasted with clay to the sides of bhatti and then ignited the kiln using coconut shell and camphor.

A pyrometer was introduced in between sand and bottle to monitor the temperature. In the first stage fire was slowly increased up to $300^{\circ} \mathrm{C}$ using dry tamarind firewood logs. New logs were introduced after completely burning the previous one to maintain the mandagni. During this stage at $184^{\circ} \mathrm{C}$ mild white fumes started coming out of the kupi which changed yellow dense fumes after sometime. An ushna salaka was inserted to remove the clogging of sulphur at the neck of kupi frequently. When the blue flame started to appear, the agni was changed to madhyama and maintained at around 500 to $550^{\circ} \mathrm{C}$. At the stage when the stoppage of blue flame at the mouth of bottle occurred and the bottom of kupi became red hot in colour the corking was done for enabling Rasasindoora formation. To confirm this, a copper plate was placed on mouth of kupi and checked if any sulphur particles on the plate. If extra sulphur particles are present the copper plate will be coated with yellow sulphur otherwise white coating of mercury will be present. A seeta salaka is also inserted to confirm the starting of rasa sindoora preparation. Corking was done with pidhana prepared earlier and sealed with mud smeared cloth for several layers. At the same time the hot sand near the neck portion was removed for enabling the sindoora formation at the neck region. The corking was done at $520^{\circ} \mathrm{C}$. After corking was completed the agni was increased to teekshna agni by placing more logs and using a blower for one yama. Temperature during this stage peaked up to $800^{\circ} \mathrm{C}$. After attaining the peak temperature, the apparatus was left undisturbed for selfcooling.

After 3 days on attaining ambient temperature, the kupi was taken out carefully and broken by using an ignited jute wick. Rasasindoora was found deposited inside the kupi especially at the neck portion with a silvery grey appearance which turned to red color on scratching. The product deposited at neck, bottom and in the cork were collected, weighed and stored separately.

\section{- Sankha bhasma nirmana}

Preparation of Sankha bhasma was done in two steps - Sankha sodhana and Sankha marana

Sodhana of sankha was done according to Rasatarangini reference, ${ }^{[7]}$ by dolayantra swedana in nimbu swarasa for ardha yama i.e. one and half hours. $500 \mathrm{~g}$ sankha was broken into small pieces and was washed thoroughly in hot water to 
remove the external impurities. $150 \mathrm{~g}$ of it was placed in a 3 layered cloth and tied well to make a pottali. A medium sized mud pot was taken and it was then added with nimbu swarasa (3 liter) to fill up to the half portion. The pottali was then hung by a rod placed over the brim of the pot so as to immerse completely in the liquid inside. The apparatus was placed in mandagni and swedana was done for one and half hour. The level of nimbu swarasa in the pot was maintained so that the pottali was completely immersed in it. After 3 hours it was taken out and the sodhita sankha pieces were washed in hot water.

According to Rasatarangini, sankha marana is done by subjecting sodhita sankha to gajaputa for two times. ${ }^{[8]} 275 \mathrm{~g}$ of sodhita sankha pieces were arranged in an earthen sarava and closed with another sarava. The sandhibandhana was done with clay smeared cloth and dried under sun. 7 layers of sandhibandhana were done by wrapping with mud smeared cloth and drying in sun successively. After sarava samputa, it was subjected to puta in muffle furnace at a temperature of $700^{\circ} \mathrm{C}$ and maintained for 2 hours. ${ }^{[9]}$ On self-cooling and reaching room temperature, on $4^{\text {th }}$ day, sarava was taken out. The cloth layers were removed and opened carefully. The burnt sankha pieces were powdered and subjected to bhavana in nimbu swarasa, chakrikas were made and dried under shade. $150 \mathrm{ml}$ of nimbu swarasa was added to completely immerse the sankha bhasma prepared in first puta and while adding the swarasa frothing of bhasma was noted. Average weight of chakrikas was $5.4 \mathrm{~g}$ and total number was 48. Totally 3 putas were done to get sankha bhasma.

\section{- Kupilu sodhana}

Sodhana of kupilu was done according to Rasatarangini reference. ${ }^{[10]} 500$ $\mathrm{g}$ of kupilu seeds were washed thoroughly in fresh water to remove mud and other external impurities. Then it was made into pottali of $150 \mathrm{~g}$ each in a double layered cloth. A medium sized mud pot was taken and pottali was hung inside it by tying on a rod. The pot was filled with milk till it completely immerses the pottali. Swedana was done under mild fire for 3 hours. Milk was added frequently to ensure complete immersion of pottali. After 3 hours, it was taken out and washed in hot water to remove the milk completely. Then the outer skin and heart shaped inner cotyledons were removed and made into 4 pieces each. After drying it was fried in ghee to make it brittle for easy powdering. It was then powdered well using a pulverizer and sieved through sieve no.85 to get a fine choorna of sudha kupilu.

\section{- Preparation of choornas of other raw drugs}

$100 \mathrm{~g}$ each of Sunthi, Maricha and Pippali were washed to remove the external impurities like mud, etc. and dried well separately. Each of them was then powdered and sieved through sieve no.85 to get fine choorna. $50 \mathrm{~g}$ of jeeraka was also powdered in the same way. $20 \mathrm{~g}$ saindhava was also powdered and kept aside.

\section{- Preparation of final product - Soolanirmoolana rasa}

For the preparation of the study drug $10 \mathrm{~g}$ each of Rasasindoora, Sankha bhasma, Amlavetasa, powders of Pippali, Sunthi, Jeeraka, Gandhaka, Saindhava, 20g Maricha choorna and $50 \mathrm{~g}$ of kupilu choorna were weighed and kept aside. All the fine powders of herbal drugs were mixed well and passed through sieve no. 85 to get a homogenous mixture. $500 \mathrm{~g}$ of fresh ardraka was purchased; the outer skin was removed and washed well to remove all the impurities. It was then crushed and swarasa was extracted without adding water. $10 \mathrm{~g}$ amlavetasa was immersed in $10 \mathrm{ml}$ of boiled and cooled water in a khalwa yantra for one hour. To this $10 \mathrm{~g}$ each of rasasindoora, sudha gandhaka choorna, sankha bhasma and saindhava choorna were added successively and grinding was done for some time after adding each drug. The homogenous mixture of herbal drugs was 
also added and ground well in the khalwa yantra to get a homogenous blend. To this mixture ardraka swarasa was added to completely immerse the mixture and ground well till the mixture attained a pill rolling consistency. Then it was rolled into pills weighing $125 \mathrm{mg}$ each which was then dried under shade. After complete drying it was stored in a clean and dry air tight container.

\section{RESULT}

200 g parada was subjected to bhavana for sodhana. During the process, the parada changed to small globules first which changed to fine powder-like particles later. During later stages of bhavana, formation of cement like particles was also observed. When washed with hot water, the form of parada was regained by joining the globules. The loss of weight was more during the bhavana in kakamachi swarasa (2.4\%) and the loss was less in chitraka kashaya bhavana $(0.11 \%)$.

\begin{tabular}{|l|l|l|}
\multicolumn{4}{c}{ Table 1. Weight of parada afte } \\
\hline Bhavana drava & $\begin{array}{l}\text { Quantity } \\
\text { used }\end{array}$ & $\begin{array}{l}\text { Quantity of parada } \\
\text { bhavana }\end{array}$ \\
\hline Kumari swarasa & $200 \mathrm{ml}$ & $200 \mathrm{~g}$ \\
\hline Chitraka kashaya & $150 \mathrm{ml}$ & $196.77 \mathrm{~g}$ \\
\hline Kakamachi swarasa & $200 \mathrm{ml}$ & $196.56 \mathrm{~g}$ \\
\hline
\end{tabular}
sodhana. The gandhaka got melted by the indirect heat given from the top of the sarava and got filtered through the cloth to the milk in the form of small gobules. The peak temperature was found to be $492^{\circ} \mathrm{C}$ and the time taken for the entire process of burning was 4 hours from the ignition of fire to complete burning of the coconut husks. $468 \mathrm{~g}$ of sodhita gandhaka was obtained after the complete procedure.

\begin{tabular}{|l|l|l|}
\hline \multicolumn{4}{|c|}{ Table 2. Gandhaka sodhana } \\
\begin{tabular}{|l|l|l|} 
Sl \\
No.
\end{tabular} & Item & Quantity \\
\hline 1 & Gandhaka & $500 \mathrm{~g}$ \\
\hline 2 & Sodhita gandhaka & $468 \mathrm{~g}$ \\
\hline 3 & Milk & $3 \mathrm{~L}$ \\
\hline 4 & Coconut husk & $\begin{array}{l}6 \text { medium sized coconut husk } \\
\text { divided to 48 pieces }\end{array}$ \\
\hline 5 & $\begin{array}{l}\text { Mud pot with } \\
\text { sarava L capacity } \\
\text { Multani mitti and } \\
\text { water }\end{array}$ & QS \\
\hline
\end{tabular}

sodhana in each bhavana drava

\begin{tabular}{|l|ll|llll} 
& Time & taken & for & Weight of & parada & after
\end{tabular}

\begin{tabular}{|l|l|}
\hline $\begin{array}{l}\text { bhavana } \\
\text { bhavana }\end{array}$ \\
\hline $8 \mathrm{hrs}$ & $196.77 \mathrm{~g}$ \\
\hline $8 \mathrm{hrs}$ & $196.56 \mathrm{~g}$ \\
\hline $8 \mathrm{hrs}$ & $191.86 \mathrm{~g}$ \\
\hline
\end{tabular}

Varitaratwa, Unnama and Rekhapoornatwa were attained after 5 hours of grinding. Nishchandratwa obtained after 75 hours of grinding. The final weight of kajjali was $240 \mathrm{~g}$.

- Kajjali bhavana was done in vatankura kashaya. $180 \mathrm{ml}$ of kashaya was used for the entire process and final weight of vatankura bhavita kajjali was $246 \mathrm{~g}$. The black colour of the kajjali was changed to deep black and three bhavana took about 30 hours to complete

- Observation during Rasasindoora preparation can be summarized as Table 3. Final weight of the product rasasindoora was $105.5 \mathrm{~g}$ out of which $93.5 \mathrm{~g}$ was from neck portion, $7.5 \mathrm{~g}$ from bottom portion and $4.5 \mathrm{~g}$ was from cork portion.

- For kajjali nirmana 120 g each sudha parada and finely powdered sudha gandhaka were ground in khalwayantra.

Table 3. Temperature chart for Rasasindoora Nirmana

\begin{tabular}{|l|l|l|}
\hline Time & Temperature in ${ }^{\circ} \mathbf{C}$ & Observations \\
\hline $9.35 \mathrm{am}$ & 30 & Kupipakwa started \\
\hline $10.50 \mathrm{am}$ & 184 & Mild white fumes present \\
\hline $11.30 \mathrm{am}$ & 250 & Mild yellow fumes present \\
\hline $12.00 \mathrm{pm}$ & 327 & Yellow fumes became dense \\
\hline $12.45 \mathrm{pm}$ & 491 & Reddish yellow fames on insertion of ushna salaka \\
\hline $1.15 \mathrm{pm}$ & 579 & Bluish flame on insertion of ushna salaka \\
\hline $1.55 \mathrm{pm}$ & 545 & Bluish flame persist \\
\hline $2.00 \mathrm{pm}$ & 541 & Intensity of flame started to decrease \\
\hline $2.15 \mathrm{pm}$ & 535 & Fumes stopped \\
\hline
\end{tabular}




\begin{tabular}{|l|l|l|}
\hline \multicolumn{3}{|c|}{ Table 3 Continued... } \\
\hline $2.20 \mathrm{pm}$ & 531 & Reddish shade at the bottom of kupi \\
\hline $2.23 \mathrm{pm}$ & 531 & Seeta salaka test positive \\
\hline $2.26 \mathrm{pm}$ & 530 & Copper coin test positive \\
\hline $2.30 \mathrm{pm}$ & 520 & Corking started \\
\hline $2.38 \mathrm{pm}$ & 518 & Corking completed and temperature intensified \\
\hline $4.30 \mathrm{pm}$ & 770 & - \\
\hline $5.30 \mathrm{pm}$ & 750 & - \\
\hline $6.30 \mathrm{pm}$ & 800 & - \\
\hline
\end{tabular}

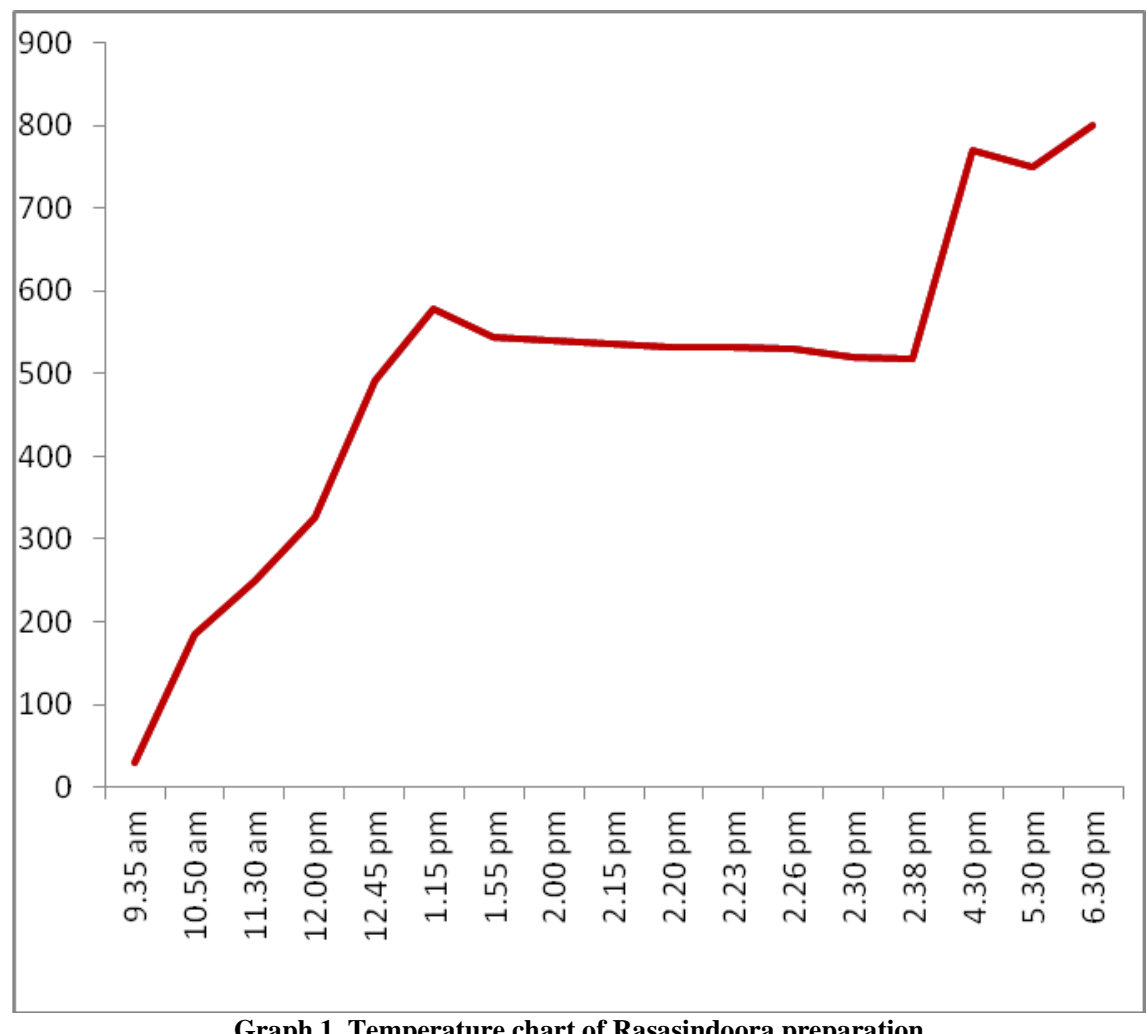

- During sankha sodhana, the colour of sankha turned white and it became more porous in texture. The colour of nimbu swarasa turned to brown which was pale yellow before the procedure. The $\mathrm{pH}$ of the nimbu swarasa before and after sodhana was found to be same. Total 4.5 liter of nimbu swarasa was used for the sodhana. $300 \mathrm{~g}$ of sankha was purified by two dolayantra swedanas and $280.5 \mathrm{~g}$ of sodhita sankha was obtained. 6.5\% loss of weight was observed after the sodhana procedure.

- During marana, after first puta the sankha pieces were found to be burned to get a greyish white color, but didn't attain an ash like or bhasma like consistency. When ground in a khalwa it was changed to fine powder. Second puta was done after making chakrikas using nimbu swarasa. While adding the swarasa frothing of bhasma was noted. The quantity of swarasa needed for the bhavana was less and drying of the mixture was fast. The bhasma obtained after 3 putas was found to be greyish white in colour. It was having no taste (niswadu) or smell.

\begin{tabular}{|l|l|l|l|}
\hline \multicolumn{3}{|c|}{ Table 4. Weight of sankha during the Marana procedure } \\
\hline $\begin{array}{l}\text { Number } \\
\text { of puta }\end{array}$ & $\begin{array}{l}\text { Weight of } \\
\text { sankha } \\
\text { before } \\
\text { marana }\end{array}$ & $\begin{array}{l}\text { Quantity of } \\
\text { Jambeera } \\
\text { swarasa }\end{array}$ & $\begin{array}{l}\text { Weight } \\
\text { sankhabhasma } \\
\text { after puta }\end{array}$ \\
\hline First puta & $275 \mathrm{~g}$ & Nil & $268 \mathrm{~g}$ \\
\hline $\begin{array}{l}\text { Second } \\
\text { puta }\end{array}$ & $268.5 \mathrm{~g}$ & $150 \mathrm{ml}$ & $261 \mathrm{~g}$ \\
\hline $\begin{array}{l}\text { Third } \\
\text { puta }\end{array}$ & $262 \mathrm{~g}$ & $150 \mathrm{ml}$ & $251.5 \mathrm{~g}$ \\
\hline
\end{tabular}

- During kupilu sodhana, Total 8 liters of milk was used for the entire procedure. After sodhana and removal of skin and cotyledons, 629 sodhita kupilu was obtained which was not brittle enough to make it to powder form. So it was fried 
in ghee. From $500 \mathrm{~g}$ of asodhita kupilu, only 262 g of sudha kupilu choorna was obtained.
- Results of powdering of drugs are given in the table no. 4 .

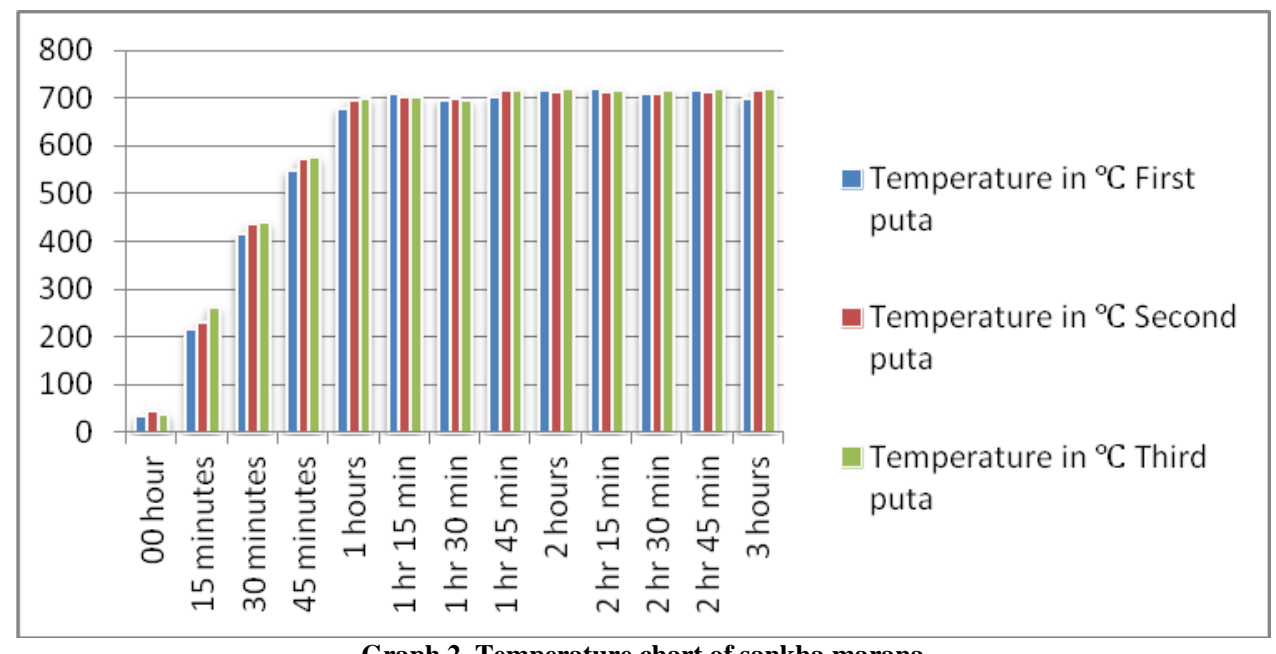

Graph 2. Temperature chart of sankha marana

\begin{tabular}{|l|l|l|l|}
\hline \multicolumn{4}{|c|}{ Table 5. Loss on powdering of drugs } \\
\hline Drug & $\begin{array}{l}\text { Quantity } \\
\text { taken }\end{array}$ & $\begin{array}{l}\text { Weight after } \\
\text { powdering }\end{array}$ & $\begin{array}{l}\text { Percentage } \\
\text { loss in weight }\end{array}$ \\
\hline Sunthi & $100 \mathrm{~g}$ & $82 \mathrm{~g}$ & $18 \%$ \\
\hline Maricha & $100 \mathrm{~g}$ & $93 \mathrm{~g}$ & $7 \%$ \\
\hline Pippali & $100 \mathrm{~g}$ & $86 \mathrm{~g}$ & $14 \%$ \\
\hline Jeeraka & $50 \mathrm{~g}$ & $36 \mathrm{~g}$ & $28 \%$ \\
\hline Sodhita Kupilu & $629 \mathrm{~g}$ & $267.5 \mathrm{~g}$ & $42.52 \%$ \\
\hline Saindhava & $20 \mathrm{~g}$ & $20 \mathrm{~g}$ & $0 \%$ \\
\hline
\end{tabular}

- For the final drug preparation amlavetasa was immersed in $10 \mathrm{ml}$ water in the khalwayantra to make it soft for the bhavana procedures and proper mixing with the ingredients. $150 \mathrm{ml}$ ardraka swarasa was used for the complete immersion of the powders of the drugs. After drying the average weight of pills was found to be $124 \mathrm{mg}$ and a total of 2134 pills were made. The pills were brown in colour and smooth in texture.
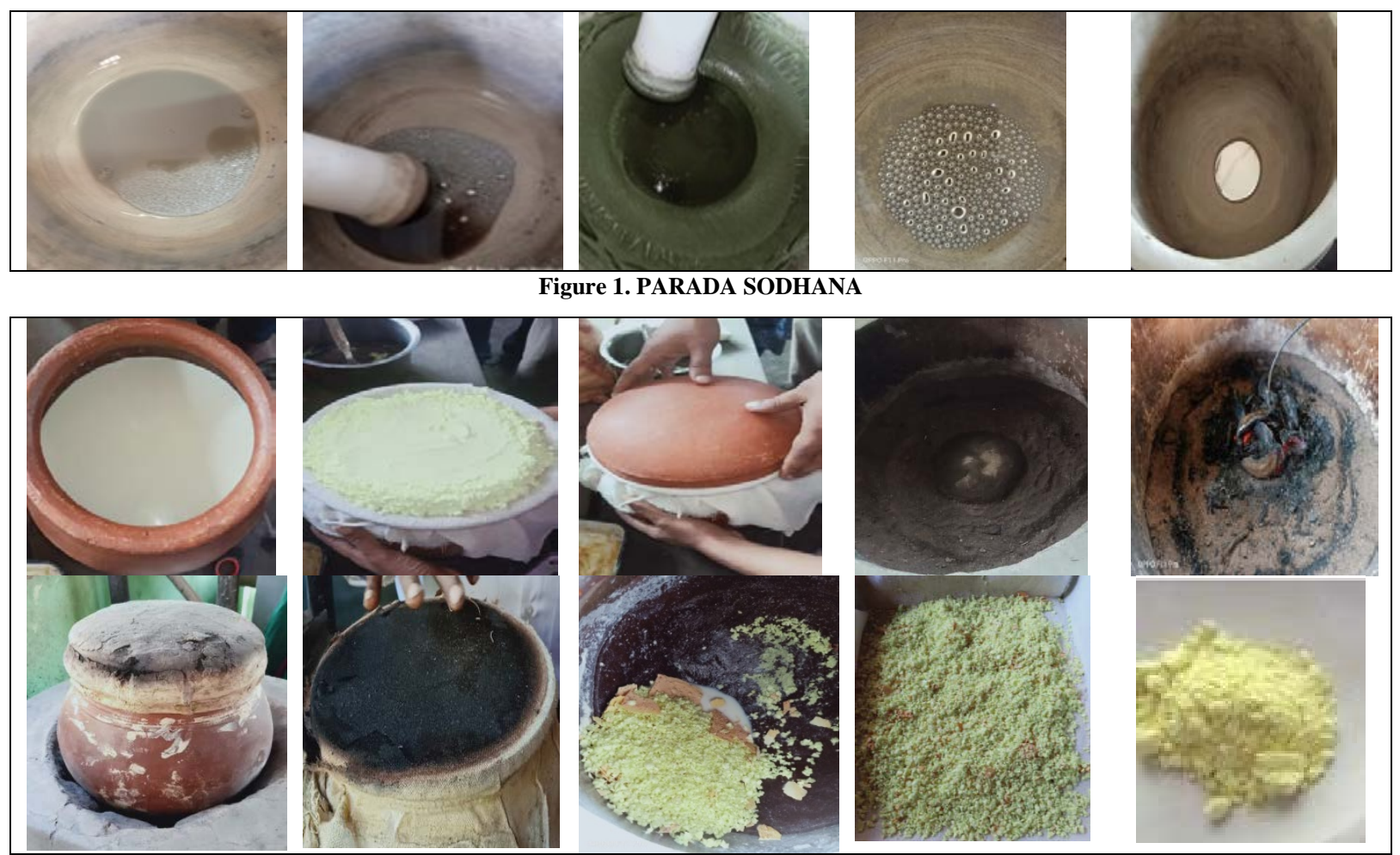

Figure 2. GANDHAKA SODHANA 


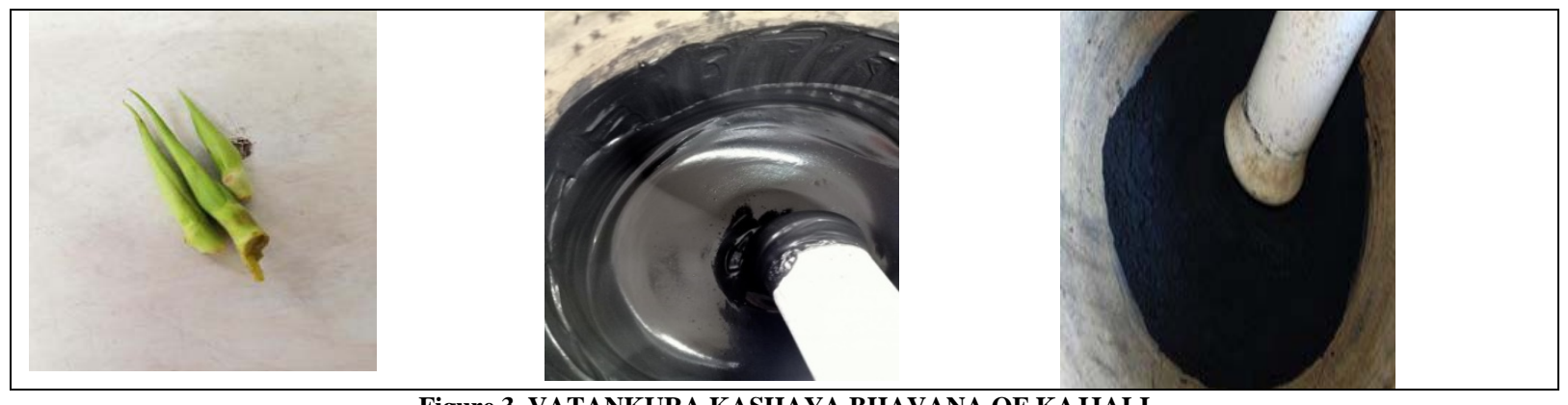

Figure 3. VATANKURA KASHAYA BHAVANA OF KAJJALI
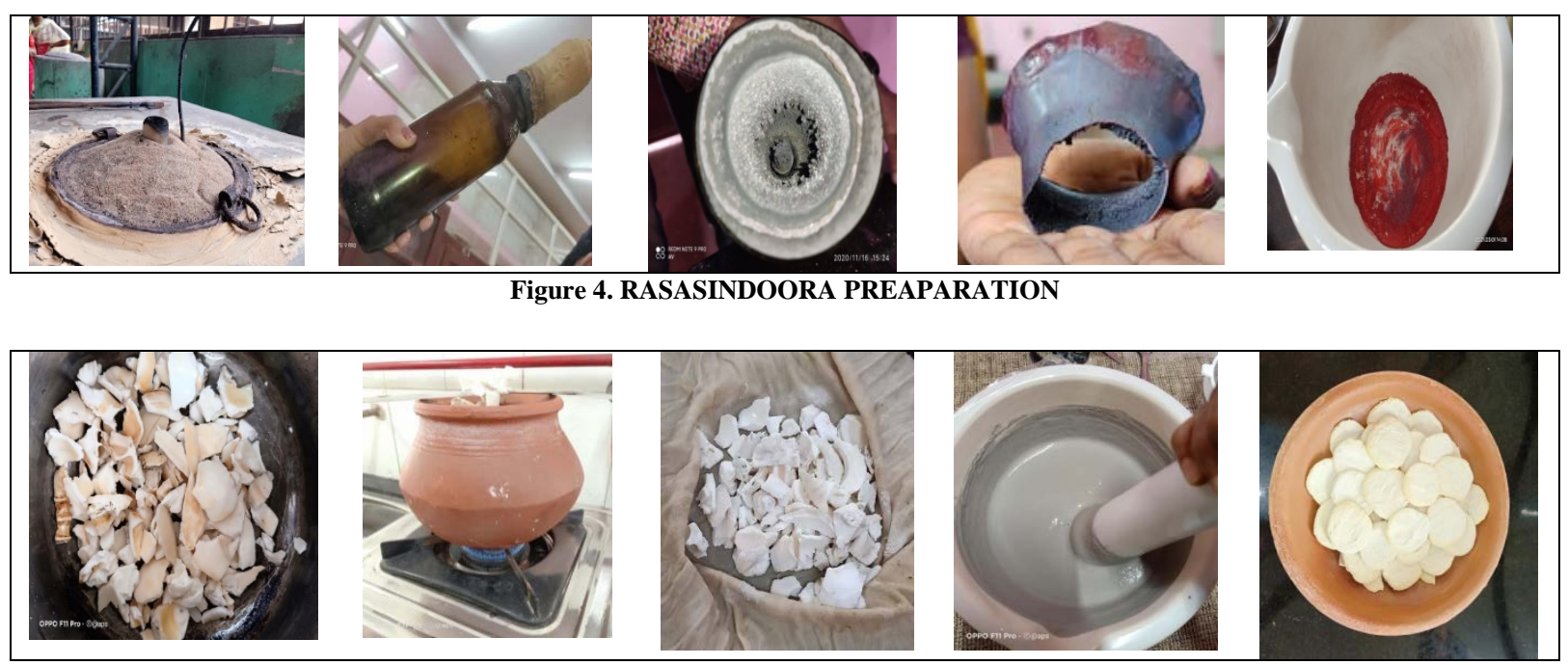

Figure 5. SANKHA SODHANA AND MARANA
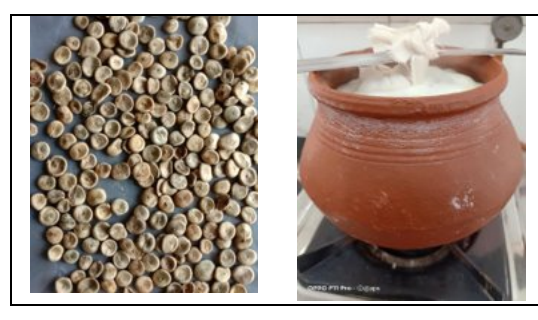

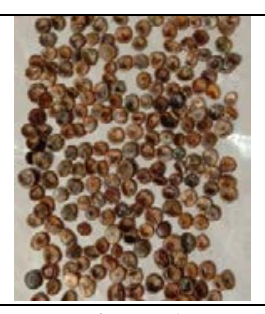

Figure 6. KUPILU SODHANA
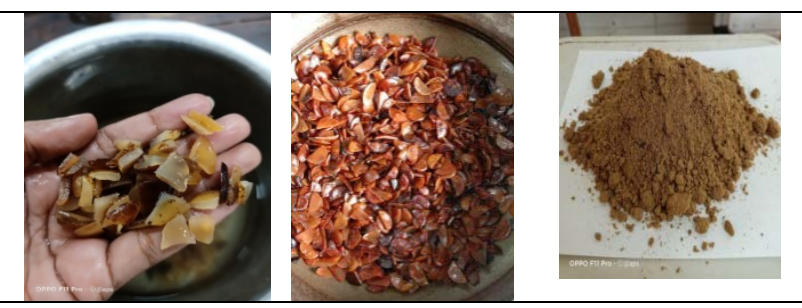

\section{DISCUSSION}

The sodhana method of parada selected here includes only three bhavana dravyas and also no visesha and samanya sodhana were required for the same. Hence the procedure was less time consuming and less man power was needed for the entire procedure. The bhavana in the above drugs were helpful in removing the doshas found in parada as the surface area of the liquid metal is reduced significantly during the process. The percentage loss was more during the bhavana in kakamachi swarasa which might be due to the gurutwa of kakamachi swarasa than other dravas used for the bhavana. The total loss of weight after the entire sodhana process of parada was $4.07 \%$. After sodhana, parada was found to be more bright, clean and more lustrous than asodhita parada. On washing with hot water, the particles got united eventually forming a single big globule and on filtering through a cotton cloth the mercury appeared clean and was bright in colour.

Gandhaka sodhana was done by koorma puta method which is suitable for sodhana of large quantity of gandhaka. The purification process was done by melting the gandhaka powder which will be filtered through the cloth into the milk which was layered above by ghrita. The presence of milk and ghrita in the purification medium will help in the removal of all types of 
gandhaka dosha. In rasasastra classics it is said that during sodhana, the cloth removes the pashana (impurities such as mud and sand), ghrita removes the visha (poisonous impurities). [11] For the preparation, 48 pieces of coconut husks were used which was standardized by in-house experiments for the maintenance of temperature at desired level. The purified gandhaka should be rinsed thoroughly in hot water till the complete removal of milk from it. This method was less time consuming and easy as compared to dalana process.

Before the preparation of kajjali, sodhita gandhaka was powdered and sieved through sieve no.120 get a very fine powder consistency. It is helpful in increasing the surface area of the gandhaka particles and thus proper grinding of kajjali. The varitaratwa, rekhapoorantwa and unnama lakshanas were obtained within 5 hours which might be due to the smaller particle size of sudhagandhaka choorna. Nischandratwa was obtained only after 75 hours of grinding. The black coloured and lustrousless powder was then subjected to vatankura kashaya bhavana. The weight was found increased by $6 \mathrm{~g}$ after three consecutive bhavanas making it 246g which might be due to the addition of herbal ingredients by the bhavana process. The temperature during the rasasindoora preparation was assessed frequently using pyrometer inserted into the sand closer to the kupi. A maximum temperature of $838^{\circ} \mathrm{C}$ was attained during the entire process. The elevation of temperature in three stages such as mridu, madhyama and teevraagni should be followed carefully for the proper paka of kajjali inside. The corking of kupi at the correct time is another important factor determining the proper paka and maximum yield of rasasindoora.

The sankha sodhana in nimbu swarasa for one and half hour as per rasatarangini reference is an easy and less time consuming sodhana method. This method was selected as it is proved that the sodhana of shankha bhasma by lemon juice method is better than sour gruel method in a study conducted in GERD patients. ${ }^{[12]}$ The acidic nature of the drava dravya and application of heat will help in making the sankha pieces porous. After first puta, the sankha became porous and was easy to powder using mortar and pestle. Second marana was done after subjecting to bhavana in nimbu swarasa and making chakrikas. In classical reference two putas are mentioned for sankha marana. But after second marana, rekhapoornatwa and varitaratwa were not attained. So third puta was done after which the lakshanas were satisfied. The varitaratwa test has to be done immediately after taking out the saravasamputa from electrical muffle furnace after self-cooling to ambient temperature and it should be kept in airtight glass jar as it is having hygroscopic nature.

The kupilu sodhana has different methods in Ayurveda classics. In this preparation dolayantra swedana in milk was selected. Dried kupilu seeds after sodhana were not able to powder easily. So it was fried in ghee for making it brittle and then powdered using pulverizer and finally sieved through sieve no.85, to get a fine powder. While powdering the other raw drugs, powdering of sunthi was the difficult one as it had more fibrous matters in it. Amlavetasa was having a tough consistency and hence powdering was difficult. So it was immersed in boiled and cooled water for one hour and ground into a fine paste. To this paste taken in a khalwa, the mineral drugs were added in the order rasasindoora, gandhaka choorna, saindhava choorna and sankha bhasma. After adding each drug grinding was done for some time to ensure proper mixing of the contents. All the herbals drugs were added after making it to a homogenous mixture. The bhavana dravya, ardraka swarasa, added in a quantity to immerse the contents completely. The bhavana was done for 3 days to attain pill rolling consistency. During the procedure and rolling pills strong smell of ardraka was present. The shade dried pills were having katu tikta pradhana rasa and the smell of 
ardraka. The pills having an average weight of $124 \mathrm{mg}$ after drying was obtained.

\section{CONCLUSION}

- While preparing Rasasindoora, proper assessment of the paka laskhanas is very important to get the final product with maximum filed. The maintenance and elevation of temperatures should be monitored frequently.

- For preparing sankha bhasma, a temperature of $700^{\circ} \mathrm{C}$ should be maintained for 2 hours. The puta should be repeated till the classical bhasma pareekshas are attained.

- The sodhita kupilu by the method of dolayantra swedana in milk should be again subjected to frying in ghrita for making it brittle and thus to make choorna maximum cost effectively.

- The method selected for sankha sodhana and parada sodhana were easy and less time consuming compared to other methods mentioned in classics.

- Gandhaka sodhana by kurmaputa method can be used to purify larger quantities of gandhaka at one single ti,e with less time and fuel consumption.

\section{Acknowledgement: None}

\section{Conflict of Interest: None}

\section{Source of Funding: None}

\section{Ethical Approval: Approved}

\section{REFERENCES}

1. Parimi Suresh, Vinaya kumara Dhannapuneni. Rasendrasara Sangraha of Sri Gopal Krishna Bhatt, second ed. Varanasi: Chaukhamba Sanskrit Sansthan; 2012. Page 1.
2. Kasinatha Sastry. Rasatarangini, 8 ed. New Delhi: Mothilal Banarasi Das; 2014. Page 679.

3. parimi Suresh, Vinaya kumara Dhannapuneni. Rasendrasara Sangraha of Sri Gopal Krishna Bhatt, second ed. Varanasi: Chaukhamba Sanskrit Sansthan; 2012. Page 28.

4. Parimi Suresh, Vinayakumari Dhannapuneni. Rasendra sara sangraha of Sri Gopalkrishna Bhatt, 2 ed. Varanasi: Chaukhambha sanskrit sansthan; 2012. Page 13

5. Gulrajsharma Mishra. Ayurvedaprakasha, 2007 ed. Varanasi: Chaukhambha Bharati Academy; 2007. Page 262

6. Krishnaveni R, Titus JM, Sreeni TV. Preparation of tarakeswara rasa- a herbo mineral formulation. Int J Health Sci Res. 2019; 9(6):171-179.

7. Kasinatha Sastry. Rasatarangini, 8 ed. New Delhi: Mothilal Banarasi Das; 2014. Page 286

8. Kasinatha Sastry. Rasatarangini, 8 ed. New Delhi: Mothilal Banarasi Das; 2014. Page 287

9. Meena V, Bhushan S and Chaudhary A: Pharmaceutical validation \& process conceptualisation of ancient Indian calcium preparation: Shankha Bhasma. Int J Pharm Sci \& Res 2019; 10(10): 4724-30. doi: 10.13040/IJPSR.0975-8232.10(10).4724-30

10. Kasinatha Sastry. Rasatarangini, 8 ed. New Delhi: Mothilal Banarasi Das; 2014. Page 678

11. Sidhinandana Misra. Rasaratna samuchaya: Sidhiprada commentary. Varanasi: Chaukhambha orientalia; 2011. Page 64

12. Ranade M, Chary DL. Comparison of two purification products of shankha bhasma: A prospective randomized control trial. J Nat Sci Biol Med. 2013 Jan;4(1):160-2.

How to cite this article: Aparna M, R Rajam. Preparation of soolanirmoolana rasa - a herbomineral formulation. Int J Health Sci Res. 2021; 11(12):21-30. DOI: https://doi.org/10.52403/ ijhsr.20211204 